\title{
Pengaruh Resiliensi dan Status Rantau Terhadap College Student Subjective Well-Being pada Mahasiswa
}

\section{The Effect of Resilience and Overseas Status on College Student Subjective Well-Being}

\author{
Ivonne Qumairi ${ }^{1}$, Asri Mutiara Putri ${ }^{* 2}$, Prida Harkina ${ }^{3}$ \\ 123 Universitas Malahayati, Bandar Lampung
}

Received July 31, 2021| Accepted December 07, 2021| Published December 15, 2021

\begin{abstract}
College students subjective well-being is an evaluation of someone's life. That is, the extent of their meaningful assessments and affective reactions indicate that their life is desirable and going well. Several factors affected college students subjective well-being, such as resilience and demographics (overseas status). The research aims to describe the effect of resilience and overseas status on college students subjective wellbeing. The type of this research is quantitative research. The data collection method used demographic data on student status, college student subjective well-being questionnaire and resilience through a google form. The subjects in this research were college students in Bandar Lampung, amounting to 451 respondents using the accidental sampling technique. In this study, data analysis used multiple regression techniques. Based on the result of statistical tests, a significance value of .000 is $.000<.05$. These show that resilience and student status simultaneously affect college students' subjective well-being with a correlation value of .640. in addition, resilience partially affect college student subjective well-being.Furthermore, these show that the higher the resilience, the higher the subjective wellbeing of the college student. However, partially overseas status does not affect college students subjective well-being. Overseas and non-overseas student status cannot affect college students subjective well-being.
\end{abstract}

Keywords: college student subjective well-being;resilience;overseas status;college student

Abstrak: College student subjective well-being merupakan evaluasi seseorang tentang kehidupannya, yaitu sejauh mana penilaian bermakna dan reaksi afektif mereka menunjukkan bahwa hidup mereka diinginkan dan berjalan dengan baik. Beberapa faktor yang mempengaruhi college student subjective well-being antara lain resiliensi dan demografi (status rantau). Penelitian ini bertujuan untuk memaparkan pengaruh resiliensi dan status Rantau terhadap college student subjective well-being pada mahasiswa. Jenis Penelitian Ini Merupakan Penelitian Kuantitatif. Metode Pengumpulan data menggunakan data demografi status mahasiswa, college student subjective well-being questionnaire dan kuesioner resiliensi melalui media google form. Subjek dalam penelitian ini yakni mahasiswa di Bandar Lampung yang berjumlah 451 responden dengan menggunakan teknik accidental sampling. Dalam Penelitian Ini Analisis data menggunakan teknik regresi berganda. Berdasarkan Hasil uji statistik, diperoleh nilai signifikansi sebesar .000 yang dimana $.000<.05$. Hal ini menunjukkan bahwa resiliensi

\footnotetext{
* Corresponding Author: Asri Mutiara Putri, email: asri@malahayati.ac.id, Universitas Malahayati, Jl. Pramuka No.27, Kemiling Permai, Kec. Kemiling, Kota Bandar Lampung, Lampung 35152, Indonesia
} 
dan status mahasiswa secara bersama-sama (simultan) mempengaruhi college student subjective well-being dengan nilai korelasi sebesar .640. Selain itu, resiliensi secara parsial mempengaruhi college student subjective well-being pada mahasiswa. Hal tersebut menunjukkan semakin tinggi resiliensi maka semakin tinggi pula college student subjective well-being pada mahasiswa. Namun, secara parsial status rantau tidak mempengaruhi college student subjective well-being pada mahasiswa. status mahasiswa rantau dan bukan rantau tidak dapat mempengaruhi college student subjective well-being pada mahasiswa.

Kata Kunci: college student subjective well-being; resiliensi; status rantau; mahasiswa

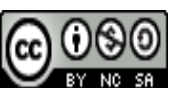

Copyright (C2021. The Authors. Published by Psikoislamika: Jurnal Psikologi dan Psikolog Islam. This is an open access article under the CC BY NO SA. Link: Creative Commons Attribution-NonCommercial-ShareAlike 4.0 International - CC BY-NC-SA 4.0

\section{Pendahuluan}

Setiap individu menginginkan college student subjective well-being didalam hidupnya,tidak terkecuali mahasiswa (Rohmad, 2014). Diener dkk., (2015) subjective well-being dapat didefinisikan sebagai evaluasi seseorang tentang kehidupannya, yaitu sejauh mana penilaian bermakna dan reaksi afektif mereka menunjukkan bahwa hidup mereka diinginkan dan berjalan dengan baik. Subjective well-being itu sendiri adalah evaluasi kognitif dan afektif seseorang atas kehidupannya. Evaluasi tersebut merangkap dua perilaku yaitu reaksi emosional terhadap peristiwa yang dialami dan penilaian kognitif kepuasaan dan pemenuhan kebutuhan hidup (Diener dkk., 2002).

Rohmad (2014) memaparkan jika individu memiliki college student subjective well-being yang tinggi menyatakan bahwa dirinya mengalami kepuasaan hidup, mengalami kegembiraan lebih sering, dan jarang mengalami emosi yang tidak menyenangkan, seperti kemarahan ataupun kesedihan. Sebaliknya, seseorang yang sering mengalami emosi negatif (kemarahan dan kecemasan), merasa tidak puas dengan hidupnya, mengalami sedikit afeksi dan kegembiraan cenderung memiliki college student subjective well-being yang rendah (dalam Rohmad, 2014). Menurut Sudjarwadi (2003) berdasarkan gambaran college student subjective well-being yang tinggi dan rendah tersebut maka mahasiswa diharapkan mempunyai college student subjective well-being yang tinggi (Fitriana, 2018). Namun pada kenyataannya, tidak semua mahasiswa mempunyai college student subjective well-being yang tinggi. Hal itu dibuktikan banyaknya fenomena yang terjadi pada mahasiswa, salah satunya terdapat 3 mahasiswa Universitas Padjajaran pada bulan maret 2019 yang ditemukan bunuh diri (Putra, 2019).

Subjective well-being sendiri memiliki beberapa faktor yang dapat mempengaruhi diantaranya adalah faktor genetik, kepribadian, faktor demografis, hubungan sosial, dukungan sosial, pengaruh masyarakat dan budaya, proses kognitif dan tujuan (Oktakarianda, 2015). Faktor demografi pada mahasiswa salah satunya adalah tempat tinggal mahasiswa, yaitu apakah dia merantau atau tinggal bersama orang tua. Tempat tinggal mempengaruhi jalan pemikiran dan persepsi seseorang untuk berprilaku dan bertindak (Rahmi, 2015). Menurut Hurk (2006) mahasiswa yang tinggal bersama orang tua atau bisa disebut mahasiswa yang bukan rantau yang mempunyai keluarga dan lingkungan pertemanan yang lebih luas di tempat tinggalnya, membuat individu tersebut cenderung sulit untuk 
membagi waktu untuk kegiatan pribadi (keluarga, teman, dan kegiatan diluar lingkungan perkuliahan) dan waktu untuk kegiatan kuliah (masuk kelas,belajar, dan mengerjakan tugas) (dalam Lerek, 2013 ; dalam Eliza, 2018). Mahasiswa bukan rantau yang tinggal di daerah sendiri bersama keluarga cenderung kurang mandiri dalam memecahkan masalah karena lebih sering menerima bantuan dan masih dalam pengawasan dan kendali orang tua (Parmawati, 2007).

Kampus-kampus di Indonesia sendiri banyak ditemui mahasiswa merantau. Salah satu alasan mahasiswa untuk merantau yaitu agar mendapatkan pendidikan yang layak. Pendidikan layak adalah hak masyarakat di Indonesia. Individu akan merantau untuk meraih cita-citanya jika di daerah tempat tinggalnya tidak memiliki tempat pendidikan yang layak (Irawati,2013; dalam Halim \& Dariyo, 2016).

Back dan Young, (dalam Fransisca, 2018) menyebutkan bahwa ketidak hadiran teman-teman dan orang tua merupakan suatu keadaan yang mempengaruhi penyesuaian diri dan sosial pada mahasiswa perantau, sehingga perpisahan dengan keluarga dan teman-teman di lingkungan lama dapat menimbulkan perasaan kesepian yang menjadi salah satu faktor penyebab depresi yang dialami oleh mahasiswa. Selain itu, menurut Devinta (2016) merantau dapat menyebabkan beberapa masalah bagi mahasiswa salah satunya adalah culture shock yang akan membuat mahasiswa rantau merasa terisolasi. Sedangkan, menurut Halim \& Dariyo (2016) merantau bagi mahasiswa juga menimbulkan perasaan loneliness yang mengindikasikan rendahnya kesejahteraan psikologis mahasiswa rantau. Berdasarkan penelitian yang dilakukan kepada 30 mahasiswa rantau di Universitas Malang menunjukkan rendahnya kesejahteraan pada mahasiswa rantau, hal ini disebabkan karena kurangnya manajemen uang dan menajemen waktu bagi mahasiswa rantau ketika berpisah dari keluarganya (Kurniawan \& Eva, 2020). Jadi, mahasiswa rantau dan bukan rantau mempunyai masalah masing-masing yang harus dihadapi dalam menjalani kehidupan perkuliahan (Eliza, 2018).

Selain itu prediktor lain yang mempengaruhi college student subjective well-being adalah resiliensi. Berdasarkan penelitian yang dilakukan (Renshaw, 2016)Dhiya (2018) menunjukkan bahwa apabila resiliensi semakin tinggi maka akan semakin tinggi college student subjective well-being individu tersebut. Menurut Ryff dan Singer (dalam Malkoc \& Yalcin,2015) menyatakan bahwa individu yang resilien mampu mempertahankan kesehatan fisik dan psikologis milik individu tersebut serta memiliki kemampuan untuk pulih lebih cepat dari stress. Oleh karena itu, dapat dilihat bahwa mahasiswa rantau dan resiliensi menjadi faktor yang mempengaruhi college student subjective well-being.

\section{Metode}

Penelitian ini menggunakan desain penelitian kuantatif korelasional dengan tujuan untuk mengetahui pengaruh resiliensi dan status rantau dengan college student subjective well-being pada mahasiswa. Penelitian ini melibatkan 2 variabel bebas yaitu resiliensi dan status rantau serta 1 variabel terikat yaitu college student subjective well-being dengan menggunakan dua buah skala yaitu skala College Student Subjective Well-being Questionnaire (CSSWO) yang diadaptasi dari Renshaw (2016) yang memiliki 16 butir pernyataan dan terdiri dari aspek - aspek yaitu: keyakinan 
terhadap pencapaian akademis (academic efficacy), kepuasan terhadap pencapaian akademis (academic satisfaction), keterhubungan dengan institusi pendidikan (school connectedness) dan kebersyukuran terhadap pendidikan yang sedang dijalani (college gratitude). Reliabilitas Untuk Skala CSSWO adalah 0.898 dengan korelasi item total berkisar antara $0.409-0.666$. Sedangkan Skala Kedua Adalah Skala Resiliensi Yang dikembangkan (Kwan, 2013) Gail M. Wagnild \& Heather M. Young (2010). Skala berbahasa inggris tersebut telah diadaptasi oleh peneliti sebelumnya yaitu Kwan (2013) sesuai dengan prosedur penerjemahan oleh (Purwanti \& Kustanti, 2018)Greco,dkk (1987). Skala tersebut mengungkap lima aspek yang meliputi, keseimbangan batin, ketekunan, kemandirian, kebermaknaan hidup, kesendirian eksistensial. Reliabilitas untuk skala Resiliensi adalah 0.936 dengan korelasi item total 0.321- 0.803. Sementara itu, status rantau akan dilihat dengan data demografi melalui pertanyaan pada awal kuesioner.

Populasi dalam penelitian ini adalah 92065 mahasiswa di Bandar Lampung dengan teknik pengambilan sampel yaitu dengan menggunakan teknik accidental sampling dan dengan menghitung jumlah subjek berdasarkan $5 \%$ populasi sehingga subjek penelitian ini minimal 400 orang mahasiswa dari 13 perguruan tinggi di Bandar Lampung. Analisis yang digunakan dalam penelitian ini yaitu dengan menggunakan metode analisis regresi berganda. Pengumpulan data dilakukan dengan menyebar skala penelitian melalui google formulir kepada mahasiswa terhitung sejak tanggal 22 Maret 2021 sampai dengan 17 April 2021. Setelah data terkumpul kemudian dilakukan scoring dengan merujuk pada blueprint masing-masing skala.

\section{Hasil}

Tabel 1.

Data Demografi Responden

\begin{tabular}{lllcc}
\hline No & Data Demografi Responden & Frekuensi (F) & Persentase (\%) \\
\hline 1 & Tingkat Semester & Semester IV & 70 & $15,5 \%$ \\
\hline & & Semester VI & 137 & $30.4 \%$ \\
\hline & Semester VIII & 230 & $51 \%$ \\
\hline & & $>$ Semester VIII & 14 & $3.1 \%$ \\
\hline 2 & Jenis Kelamin & Perempuan & 284 & $37 \%$ \\
\hline & & LakiLaki & 167 & $63 \%$ \\
\hline 3 & Usia & Rantau & 212 & $47 \%$ \\
\hline & & Bukan Rantau & 239 & $53 \%$ \\
\hline
\end{tabular}

Berdasarkan tabel 1, dapat diketahui bahwa subjek penelitian didominasi oleh mahasiswa semester VIII, berjenis kelamin perempuan, dan berstatus bukan mahasiswa rantau.

Tabel 2.

Deskripsi Data Penelitian

\begin{tabular}{lclcc}
\hline Variabel & X Min & X Max & Mean & SD \\
\hline CSSWB & 16 & 112 & 64 & 16 \\
\hline Resiliensi & 24 & 168 & 96 & 24 \\
\hline
\end{tabular}

Berdasarkan tabel 2, dapat diketahui bahwa variabel College Student Subjective Well-Being (CSSWB) memiliki nilai terendah ( $\mathrm{min}$ ) yaitu 16 dan nilai tertinggi (maks) adalah 112 . Kemudian ratarata (mean) dari CSSWB adalah 64 dengan standar deviasi (SD) sebesar 16. Sementaraitu, variabel 
resiliensi diketahui memiliki nilai-nilai terendah ( $\mathrm{min}$ ) adalah 24 dan nilai tertinggi (maks) adalah 168. standar deviasi Resiliensi yaitu 24 dan nilai rata-rata yaitu 96.

\section{Kategorisasi Skor Variabe IPenelitian}

Kategori dasi variabel penelitian memberikan gambaran kategori masing-masing dari variabel college student subjective well-being, resiliensi dan status rantau yang dimiliki subjek.

Tabel 3.

Kategorisasi Skor College Student Subjective Well-Being

\begin{tabular}{llll}
\hline Kategori & \multicolumn{1}{c}{ Skor } & Frekuensi (F) & Persentase (\%) \\
\hline Sangat Rendah & $\mathrm{X}<40$ & 0 & $0 \%$ \\
\hline Rendah & $40<\mathrm{X} \leq 56$ & 0 & $0 \%$ \\
\hline Sedang & $56<\mathrm{X} \leq 72$ & 32 & $7,1 \%$ \\
\hline Tinggi & $72<\mathrm{X} \leq 88$ & 171 & $39,02 \%$ \\
\hline Sangat Tinggi & $\mathrm{X}>88$ & 248 & $53.88 \%$ \\
\hline Jumlah & & $\mathbf{4 5 1}$ & $\mathbf{1 0 0 \%}$ \\
\hline
\end{tabular}

Berdasarkan tabel 3, terlihat bahwa subjek penelitian memiliki college student subjective wellbeing yang tergolong sangat tinggi, yaitu dengan persentase sebesar $53,88 \%$.

Tabel 4.

Kategorisasi Aspek College Student Subjective Well-Being

\begin{tabular}{ccccccc}
\hline \multirow{2}{*}{ Aspek } & \multicolumn{6}{c}{ Kategori } \\
\cline { 2 - 7 } & $\begin{array}{c}\text { Sangat } \\
\text { Rendah }\end{array}$ & Rendah & Sedang & Tinggi & $\begin{array}{c}\text { Sangat } \\
\text { Tinggi }\end{array}$ & $\begin{array}{c}\text { Persentase } \\
(\%)\end{array}$ \\
\hline Kepuasaan Akademik & $0 \%$ & $1.33 \%$ & $17.7 \%$ & $35.7 \%$ & $45.9 \%$ & $100 \%$ \\
\hline Efisiensiak ademik & $0.89 \%$ & $3.10 \%$ & $21.95 \%$ & $32.82 \%$ & $41.24 \%$ & $100 \%$ \\
\hline Keterhubungan Sekolah & $0.22 \%$ & $1.77 \%$ & $21.29 \%$ & $38.80 \%$ & $37.92 \%$ & $100 \%$ \\
\hline $\begin{array}{c}\text { Bersyukur dengan } \\
\text { perguruan Tinggi }\end{array}$ & $0 \%$ & $0 \%$ & $2.22 \%$ & $12.64 \%$ & $85.14 \%$ & $100 \%$ \\
\hline
\end{tabular}

Berdasarkan tabel 4 dapat diketahui bahwa sebagian besar subyek penelitian memiliki college student subjective well-being dalam kategori sangat tinggi yakni pada aspek Kepuasan Akademik (45.9\%), aspek Efesiensi Akademik (41.24\%), aspek Bersyukur dengan Perguruan tinggi (85.14\%) sedangkan berada dalam kategori tinggi yakni pada aspek Keterhubungan Sekolah (38.80). 
Tabel 5.

Kategorisasi Resiliensi

\begin{tabular}{clll}
\hline Kategori & Skor & Frekuensi $(\mathrm{F})$ & Persentase (\%) \\
\hline Sangat Rendah & $\mathrm{X}<60$ & 1 & $0.22 \%$ \\
\hline Rendah & $60<\mathrm{X} \leq 84$ & 1 & $0.22 \%$ \\
\hline Sedang & $84<\mathrm{X} \leq 108$ & 33 & $7.32 \%$ \\
\hline Tinggi & $108<\mathrm{X} \leq 132$ & 127 & $28.16 \%$ \\
\hline Sangat Tinggi & $\mathrm{X}>132$ & 289 & $64.08 \%$ \\
\hline Jumlah & & 451 & $100 \%$ \\
\hline
\end{tabular}

Berdasarkan tabel 5 terlihat bahwa sebanyak 289 orang subjek memiliki skor sangat tinggi (64.08).

Tabel6.

Kategorisasi Aspek Resiliensi

\begin{tabular}{llllllc}
\hline \multicolumn{1}{c}{ Aspek } & \multicolumn{1}{c}{ Sangat } \\
& Rendah & Rendah & Sedang & Tinggi & $\begin{array}{c}\text { Sangat } \\
\text { Tinggi }\end{array}$ & $\begin{array}{c}\text { Persentase } \\
(\%)\end{array}$ \\
\hline KeseimbanganBatin & $0.2 \%$ & $0.7 \%$ & $9.5 \%$ & $28.8 \%$ & $60.8 \%$ & $100 \%$ \\
\hline Ketekunan & $0.22 \%$ & $0.66 \%$ & $13.1 \%$ & $28.60 \%$ & $57.42 \%$ & $100 \%$ \\
\hline Kemandirian & $0.44 \%$ & $0 \%$ & $6.65 \%$ & $25.28 \%$ & $67.63 \%$ & $100 \%$ \\
\hline KebermaknaanHidup & $0.66 \%$ & $5.1 \%$ & $30.16 \%$ & $0,22 \%$ & $63.86 \%$ & \\
\hline KesendirianEksistensial & $0.22 \%$ & $1.11 \%$ & $8.43 \%$ & $21.73 \%$ & $68.51 \%$ & $100 \%$ \\
\hline
\end{tabular}

Berdasarkan tabel diatas dapat diketahui bahwa sebagian besar subyek penelitian memiliki resiliensi dalam kategori sangat tinggi yakni pada aspek keseimbangan batin (60,8\%), aspek ketekuman $(57,42 \%)$, aspek kemandirian $(67,63)$, aspek kebermaknaan hidup $(63,86 \%)$, dan aspek kesendirian eksistensial (68,51\%).

\section{Hasil Uji Asumsi}

Penelitian Ini Menggunakan uji hipotesis atau uji korelasi serta analisis tambahan lainnya, tetapi sebelum peneliti memulai menganalisa data maka hendaknya perlu dilakukan uji persyaratan analisis yaitu uji asumsi. Uji asumsi yang dimaksud berupa uji normalitas, uji multikolinearitas, uji linieritas, uji heteroskedasitas dan uji autokorelasi. Uji normalitas dalam penelitian ini menggunakan uji statistik One-Sample Kolmogorov Smirnov Test dengan nilai signifikansi sebesar 0,179, grafik histogram dan grafik P-P Plot dimana dari ketiga hasil tersebut menunjukkan data berdistribusi normal. Sedangkan uji linearitas dan homoskedastisitas dilakukan dengan melihat diagram scatterplot dan menunjukkan bahwa data bersifat linier dan tidak terjadi heterokedasitas. Selanjutnya uji multikolinieritas diperoleh nilai VIF= 1.017 dan autokorelasi diperoleh nilai DurbinWatson sebesar 1.826 hal tersebut menunjukkan bahwa tidak terjadi multikolinieritas dan tidak adanya autokorelasi. Sehingga, uji asumsi dalam penelitian ini terpenuhi. 


\section{Hasil Uji Hipotesis}

Setelah uji asumsi variabel terpenuhi, maka selanjutnya dilakukan uji hipotesis yaitu untuk menjelaskan ada atau tidaknya pengaruh antara variabel bebas dengan variabel tergantung. Adapun hipotesis yang diajukan dalam penelitian ini adalah resiliensi dan status rantau mempengaruhi college student subjective well-being pada mahasiswa. Uji hipotesis ini dilakukan dengan menggunakan analisis regresi linier berganda yang dihitung dengan bantuan SPSS 22.0 for windows. Berikut adalah uji hipotesis yang dilakukan

Tabel7.

Uji StatistikSimultan (Uji F)

\begin{tabular}{llllll}
\hline Model & & Sum of Squares & Df & Mean Square & F \\
\hline 1 & Regression & 20908.386 & 2 & 10454.193 & $155.348^{* *}$ \\
\hline & Residual & 30148.253 & 448 & 67.295 & \\
\hline & Total & 51056.639 & 450 & & \\
\hline
\end{tabular}

$* \mathrm{p} p .01$

Berdasarkan tabel 7 menunjukkan bahwa secara bersama-sama semua variabel independen yaitu resiliensi dan status rantau secara bersama-sama (simultan) mempengaruhi college student subjective well-being $(\mathrm{p}<.01)$.

Tabel 8.

Uji Koefisien Determinasi $\left(R^{2}\right)$

\begin{tabular}{lllll}
\hline Model & $\mathrm{R}$ & $\mathrm{R}$ Square & Adjusted R Square & Std. Error of the Estimate \\
\hline 1 & .640 & .410 & .407 & 8.203 \\
\hline
\end{tabular}

Berdasarkan tabel 8 dapat dilihat bahwa nilai $R$ Square yaitu sebesar .410 yang menunjukkan bahwa variabel college student subjective well-being dapat dijelaskan oleh variabel resiliensi dan status rantau yaitu sebesar $41 \%$. Sedangkan sisanya yaitu sebesar $59 \%$ dijelaskan oleh faktor-faktor lain di luar model analisis dalam penelitian ini.

Tabel 10.

Uji Statistik Parsial (Uji T)

\begin{tabular}{llllll}
\hline Model & \multicolumn{2}{l}{ Unstandardized Coefficients } & Standardized Coefficients & $\mathrm{T}$ \\
\hline & $\mathrm{B}$ & Std. Error & Beta & \\
\hline 1 & (Constant) & 7.376 & 2.967 & & $12.597^{* *}$ \\
\hline & Status Rantau & -.518 & .780 & -.024 & -.664 \\
\hline & Resiliensi & .382 & .022 & .643 & $17.553^{* *}$ \\
\hline & & & &
\end{tabular}

Berdasarkan hasil diatas dapat dilihat bahwa bahwa t-hitung dari resiliensi yakni 17.553 dengan dengan koefisien Beta $=.643$ dan taraf signifikansi $p<.01$. Berdasarkan tabel diatas dapat dilihat bahwa t hitung dan koefisien beta dari status mahasiswa didapatkan hasil yaitu -.664 dengan koefisien beta -.024 dan taraf signifikansi $p>.01$. Hal ini menunjukkan bahwa dari dua variabel bebas, variabel resiliensi memberikan sumbangan lebih besar terhadap college student subjective well-being dibandingkan status rantau. 
Berdasarkan hasil uji hipotesis di atas dapat disimpulkan bahwa hipotesis dalam penelitian ini dapat di terima, yaitu resiliensi dan status rantau mempengaruhi college student subjective wellbeing pada mahasiswa. Setelah melakukan uji hipotesis peneliti mencari sumbangan efektif dan sumbangan relatif. Jumlah sumbangan relatif dari semua variabel independen adalah $100 \%$ atau sama dengan 1. Sedangkan jumlah sumbangan efektif dari semua variabel dependen adalah sama dengan jumlah nilai yang ada pada $R$ Square yaitu .410 atau $41 \%$.

Tabel 11.

Sumbangan Efektif dan Sumbangan Relatif

\begin{tabular}{lcl}
\hline \multicolumn{1}{c}{ Variabel } & SE (\%) & SR (\%) \\
\hline Resiliensi & $40 \%$ & $55,6 \%$ \\
\hline Status rantau & $32 \%$ & $44,4 \%$ \\
\hline
\end{tabular}

\section{Diskusi}

Berdasarkan hasil dari penelitian menggunakan teknik analisis regresi berganda ini, menunjukkan bahwa terdapat pengaruh yang signifikan antara resiliensi dan status rantau dengan college student subjective well-being pada mahasiswa. Hasil Analisa statistika tersebut menunjukan nilai koefisien korelasi sebesar $r=0.640$ dengan nilai signifikansi 0.000 dan $R$ square $=0,410$ yang menunjukan bahwa secara simultan variabel bebas yaitu resiliensi dan status rantau memiliki $41 \%$ sumbangan sebagai prediktor dalam mempengaruhi college student subjective well-being sedangkan sisanya $59 \%$ dipengaruhi oleh faktor lain.

Penelitian ini menunjukkan bahwa resiliensi dan status rantau mempengaruhi college student subjective well-being mahasiswa. Berdasarkan telaah pustaka, diketahui bahwa belum ada yang meneliti mengenai pengaruh antara resiliensi dan status rantau dengan college student subjective well-being pada mahasiswa. Jadi, penelitian ini merupakan penelitian pertama yang dilakukan untuk meneliti tiga konstruk tersebut.

Berdasarkan hasil analisis data yang dilakukan diketahui ada pengaruhpositif antara resiliensi dengan college student subjective well-being. Secara parsial resiliensi menyumbang $41,1 \%$ terhadap college student subjective well-being. Maka dari hasil uji hipotesis ini berarti semakin tinggi resiliensi, semakin tinggi pula college student subjective well-being pada mahasiswa. Hasil penelitian ini serupa dengan penelitian yang dilakukan Purwanti \& Kustanti ( 2018) yang menunjukkan hasil bahwa semakin tinggi resiliensi maka akan semakin tinggi pula subjective well-being nya. Sebaliknya, semakin rendah resilliensi maka semakin rendah pula subjective well-being nya. Oleh karena itu, resiliensi memiliki peran mendasar pada subjective well-being dan juga dianggap efektif dalam meningkatkan subjective well-being. untuk mampu mencapai tingkat College Student Subjective Wellbeing tersebut dibutuhkan individu yang mampu dalam menghadapi permasalahan, salah satu kunci tercapainya College Student Subjective Well-being adalah resiliensi (Amelasasih dkk., 2019).

Menurut (Hendriani, 2018; Reivich \& Shatte, 2002), resiliensi merupakan kemampuan seseorang untuk bertahan, bangkit, dan menyesuaikan dengan kondisi yang sulit. Menurut Handoyo (dalam Hendriani, 2018) tantangan kehidupan semakin lama semakin besar, dengan kondisi tersebut, keberhasilan dalam kehidupan ditentukan tidak hanya oleh kemampuan untuk meraih 
kebahagiaan, tetapi juga kemampuan untuk merespon dan menghadapi persoalan dan kegagalan. Beberapa individu mampu bertahan dalam menghadapi masalah yang sedang dialami bahkan mampu bangkit dari keterpurukan setelah masalah tersebut terjadi hal ini karena individu tersebut memilki kemampuan yang disebut dengan resiliensi. Kemampuan resiliensi tersebut akan mengoptimalkan college student subjective well-being pada diri mahasiswa.

Hasil penelitian sebelumnya pula mengenai hubungan antara resiliensi dengan college student subjective well-being ditunjukkan melalui penelitian yang dilakukan oleh Gumintang, (2020) bahwa terdapat hubungan signifikan positif antara resiliensi dan subjective well-being, yang mana berarti semakin tinggi tingkat resiliensi subjek maka akan tinggi pula subjective well-being-nya. Ketika individu memiliki resiliensi yang tinggi, mereka cenderung lebih kuat ketika berada pada kondisi yang buruk dan ketika mengalami perubahan mereka akan merasa lebih mudah beradaptasi (dalam Kurniawan \& Eva, 2020).

Hasil penelitain ini juga menunjukan bahwa status rantau tidak mempengaruhi college student subjective well-being pada mahasiswa. Dikarenakan penelitian ini adalah penelitian pertama yang melihat status mahasiswa dengan college student subjective well-being, maka tidak ada hasil penelitian lain yang dapat dibandingkan oleh peneliti. Hanya saja penelitian yang ditemukan oleh peneliti mengenai mahasiswa rantau dengan college student subjective well-being. Hasil penelitian yang dilakukan oleh Kurniawan \& Eva (2020)menyatakan bahwa berdasarkan hasil penelitian yang dilakukan sebagian besar mahasiswa rantau angkatan 2019 Universitas Negeri Malang memiliki kesejahteraan psikologis pada kategori tinggi...Artinya mahasiswa rantau berfungsi secara positif pada kehidupan sehari-hari dan dapat melaksanakan kegiatan kuliah tanpa merasa keberatan dengan masalah-masalah yang muncul (Eliza, 2018).

Menurut Renshaw (2016) College student subjective well-being adalah penilaian individu terhadap kedua perilaku pribadi (kognisi dan emosi) dan perilaku masyarakat (tindakan verbal dan fisik) yang baik dan sesuai dengan konteks. college student subjective well-being juga merupakan evaluasi kognitif dan afektif seseorang atas kehidupannya. Evaluasi yang dimaksud tersebut, yaitu college student subjective well-being ditentukan oleh bagaimana cara individu mengevaluasi informasi dari kejadian yang dialami.

Dalam penelitiannya, Renshaw (2016) menyebutkan 4 karakteristik college student subjective well-being berbasis kehidupan kampus. Aspek pertama adalah kepuasan akademik yang merupakan keyakinan seseorang terhadap kemampuan dirinya untuk menampilkan dan menyelesaikan suatu tugas, aspek kedua efisiensi akademik yang merupakan penilaian subjektif seseorang terhadap kualitas hidup akademiknya, aspek ketiga keterhubungan sekolah yaitu persepsi pada hubungan harmonis atau suportif dan aspek terakhir bersyukur dengan perguruan tinggi yaitu respon emosi yang positif dirasakan ketika menerima keuntungan dan manfaat tertentu.

Berdasarkan hasil penelitian terhadap aspek-aspek dari college student subjective well-being didapatkan hasil yaitu : pada aspek Academic Eficacy (kepuasan akademik) sebagian besar berada pada kategori sangat tinggi yang berjumlah 207 orang, pada aspek Academic Satisfaction (Efesiensi Akademik) sebagian besar berada pada kategori sangat tinggi yang berjumlah 186 orang, pada aspek 
School Connectedness (Keterhubungan Sekolah) sebagian besar berada pada kategori tinggi yang berjumlah 175 orang dan pada aspek College Gratitude (Bersyukur dengan Perguruan tinggi) sebagian besar berada pada kategori sangat tinggi yang berjumlah 384 orang. Maka secara keseluruhan dapat disimpulkan bahwa mahasiswa yang menjadi subjek dalam penelitian ini sebagian besar memiliki college student subjective well-being yang sangat tinggi.

Resiliensi memiliki lima karakteristik yang saling terkait menurut Wagnild dan Young (dalam Shaikh \& Kauppi, 2010) yaitu, kesimbangan batin, ketekunan, kemandirian, kebermaknaan hidup. Dan kesendirian eksistensial Berdasarkan hasil penelitian terhadap aspek-aspek dari resiliensi didapatkan hasil bahwa kelima aspek berada dalam kategori sangat tinggi dengan jumlah responden yaitu: pada aspek keseimbangan batin berjumlah 274 orang, pada aspek ketekunan berjumlah 305 orang, pada aspek kemandirian yang berjumlah 313 orang dengan persentase sebesar $69,40 \%$, pada aspek kebermaknaan hidup berjumlah 288 orang,dan pada aspek kesendirian eksistensial berjumlah 309. Maka secara keseluruhan dapat disimpulkan bahwa mahasiswa yang menjadi subjek dalam penelitian ini sebagian besar memiliki resiliensi yang sangat tinggi.

Dengan demikian setelah melalui prosedur penelitian dan analisis data yang sesuai. Penelitian Ini telah mencapai tujuannya yaitu mampu memaparkan bahwa resiliensi dan status rantau memiliki pengaruh yang positif dengan college student subjective well-being pada mahasiswa serta berhasil membuktikan hipotesis yang berbunyi resiliensi dan status rantau mempengaruhi college student subjective well-being pada mahasiswa

\section{Kesimpulan}

Berdasarkan Hasil Penelitian yang diperoleh, maka dapat disimpulkan bahwa variabel resiliensi dan status rantau mempengaruhi college student subjective well-being. Sehingga, variabel resiliensi dan status rantau dapat menjadi prediktor variabel college student subjective well-being. Selanujutnya secara parsial resiliensi mempengaruhi college student subjective well-being pada mahasiswa. Artinya, semakin tinggi resiliensi akan semakin tinggi pula college student subjective wellbeing pada mahasiswa. Begitupun sebaliknya, semakin rendah resiliensi maka semakin rendah college student subjective well-being pada mahasiswa. Namun, status rantau tidak mempengaruhi college student subjective well-being pada mahasiswa. Artinya, mahasiswa rantau ataupun bukan rantau tidak mempengaruhi college student subjective well-being pada mahasiswa.

Penelitian Ini telah dilaksanakan dengan baik dan tujuan dari penelitian telah tercapai, akan tetapi penelitian ini tetap memiliki keterbatasan. Keterbatasan penelitian yaitu pada masa pandemi Covid-19 saat ini yang mengharuskan para mahasiswa belajar dirumah, sehingga peneliti tidak dapat mengontrol langsung tempo mengerjakan, kuota, sinyal dan terjadinya gangguan pada google form. Selain itu, kemungkinan jawaban tidak sesuai dengan keadaan yang sebenarnya dari responden karena alasan-alasan tertentu, meskipun peneliti sudah berupaya menjelaskan kepada responden untuk jujur dalam menjawab pernyataan yang sesuai dengan keadaan sebenarnya. 


\section{Referensi}

Amelasasih, P., Aditama, S., \& Wijaya, M. R. (2019). Resiliensi akademik dan subjective well-being pada mahasiswa. Proceeding National Conference Psikologi UMG 2018, 1(1), 161-167.

Devinta, M. (2016). Fenomena culture shock (gegarbudaya) pada mahasiswa perantauan di Yogyakarta. E-Societas, 5(3).

Diener, E., Lucas, R. E., \& Oishi, S. (2002). Subjective well-being: The science of happiness and life satisfaction. Handbook of Positive Psychology, 2, 63-73.

Diener, E., Oishi, S., \& Lucas, R. E. (2015). National accounts of subjective well-being. American Psychologist, 70(3), 234.

Eliza, F. F. (2018). Perbedaan kebutuhan dukungan sosial pada mahasiswa rantau dengan mahasiswa tidak merantau di fakultas psikologi universitas sumatera utara.

Fitriana, N. (2018). Perilaku Makan Dan Kesejahteraan Subjektif Mahasiswa. Insight: Jurnal Ilmiah Psikologi, 20(2), 104-111.

Fransisca, N. (2018). Hubungan antara dukungan sosial dengan psychological well-being pada mahasiswa perantau di Universitas Katolik Soegijapranata [(Doctoral dissertation,]. Unika Soegijapranata Semarang.

Gumintang, A. (2020). Hubungan antara resiliensi dengan kesejahteraan psikologis pada lansia di Pondok Lansia Al-Islah Kota Malang [(Doctoral dissertation,]. Universitas Islam Negeri Maulana Malik Ibrahim.

Halim, C. F., \& Dariyo, A. (2016). Hubungan psychological well-being dengan loneliness pada mahasiswa yang merantau. Jurnal Psikogenesis, 4(2), 170-181.

Hendriani, W. (2018). Resiliensi psikologis: Sebuah pengantar. Kencana.

Hurk, M. V. D. (2006). The relation between self-regulated strategies and individual study time, prepared participation and achievement in a problem-based curriculum. Active Learning in Higher Education, 7(2), 155-169.

Kurniawan, S. R., \& Eva, N. (2020). Hubungan antara dukungan sosial dengan kesejahteraan psikologis pada mahasiswa rantau. Seminar Nasional Psikologi UM, 1(1)).

Kwan, M. (2013). Hubungan antara religiusitas dan resiliensi. Skripsi. Universitas Sanata Dharma.

Oktakarianda, R. (2015). Subjective well being ditinjaudari faktor demografi (status pernikahan, jenis kelamin, tingkat pendidikan, status pekerjaan dan jumlah tanggungan) pada Petani Sawit [(Doctoral dissertation,]. Universitas Islam Negeri Sultan Syarif Kasim Riau.

Parmawati, R. (2007). Perbedaan motivasi berprestasi antara mahasiswa perguruan tinggi negeriswasta ditinjau dari mahasiswa pendatang-bukan pendatang [(Doctoral dissertation,]. Universitas Muhammadiyah Surakarta.

Purwanti, D. A., \& Kustanti, E. R. (2018). Hubungan antara resiliensi dengan psychological well-being pada ibu yang memiliki anak dengan gangguan autis. Empati, 7(1), 283-287.

Putra, W. (2019). DetikNews. JawaBarat. https://news.detik.com/berita-jawa-barat/d-4463416/tigamahasiswa-unpad-bunuh-diri-psikiater-ungkap-penyebabnya

RAHMI, N. A. (2015). Pengaruh faktor demografi dan non demografi terhadap tingkat fertilitas di [(Doctoral dissertation,]. UNIVERSITAS AIRLANGGA. 
Renshaw, T. (2016). The college student subjective well-being questionnaire: a brief, multidimensional measure of undergraduate's covitality. Journal of Happiness Studies, 17(2), 463-484.

Rohmad, R. (2014). Hubungan antara dukungan sosial dengan kesejahteraan subjektif pada mahasiswa fakultas psikologi universitas muhammadiyah Surakarta [(Doctoral dissertation,]. Universitas Muhammadiyah Surakarta.

Shaikh, A., \& Kauppi, C. (2010). Deconstructing resilience: Myriad conceptualizations and interpretations. 
This page is intentionally left blank 